\title{
Heterogenization of $\left[\mathrm{Cu}\left(2,2^{\prime}-\mathrm{bpy}\right) \mathrm{Cl}_{2}\right]$ and $\left[\mathrm{Cu}(1,10-\mathrm{phen}) \mathrm{Cl}_{2}\right]$ on Polyoxometalates: New Catalysts for the Selective Oxidation of Tetralin
}

\author{
M. BOLTZ, A. BLANC, G. LAUGEL, P. PALE, B. LOUIS* \\ Laboratoire de Synthèse et Réactivité Organiques, Institut de Chimie, UMR 7177 CNRS, Université de Strasbourg, \\ 4 rue Blaise Pascal, 67000, Strasbourg Cedex, France
}

\begin{abstract}
Mononuclear Cu(II) bipyridine (1) and phenantroline complexes (2) were synthesized and immobilized by different procedures on $\mathrm{H}_{3} \mathrm{PW}_{12} \mathrm{O}_{40}$ polyoxometalate (POM). Characterization by XRD and SEM-EDX were performed to assess the preservation of the Keggin structure and stoichiometry of the complex. The immobilized complexes were tested as heterogeneous catalysts for the partial oxidation of tetralin (1,2,3,4-tetrahydronaphthalene) using hydrogen peroxide as oxidant in acetonitrile/water as solvent. $\left[\mathrm{Cu}\left(2,2^{\prime}-\mathrm{bpy}\right) \mathrm{Cl}\right]\left[\mathrm{H}_{2} \mathrm{PW}_{12} \mathrm{O}_{40}\right]$ and [Cu(1,10-phen) $\mathrm{Cl}]\left[\mathrm{H}_{2} \mathrm{PW}_{12} \mathrm{O}_{40}\right]$ oxidized tetralin at room temperature, with 16\% conversion with (2), to 1-tetralone and 2-tetralone with $83 \%$ selectivity. However, the selectivity for 1-tetralone was only 56\%. Different preparation methods for the heterogenization of these complexes on the POM Keggin unit were compared and used to enhance the selectivity to 1-tetralone to $75 \%$.
\end{abstract}

Key words: tetralin; partial oxidation; $\mathrm{Cu}(\mathrm{II})$ complexes; 2,2'-bipyridine; 1,10-phenantroline; hydrogen peroxide; polyoxometalate CLC number: O643 Document code: A

Received 29 March 2011. Accepted 25 April 2011.

*Corresponding author.Tel: +33-3-6885-1488; E-mail: blouis@unistra.fr

Tetralone is a keto derivative of tetralin, which is a tetrahydrogenated form of naphthalene. Tetralone is used as a solvent and plastic softener. It is also the reactive intermediate to pharmaceutical, agrochemical, and dye compounds of industrial importance, such as the insecticide carbaryl, the antidepressant sertraline, and the antihypertensive drug benazepril [1-3]. Tetralone can be produced by different chemical processes, but the main processes are Friedel-Crafts acylation of aromatics with acid halide/anhydride or oxidation reactions. Unfortunately, these processes use, respectively, stoichiometric amounts of corrosive $\mathrm{AlCl}_{3}$ as catalyst and $\mathrm{KMnO}_{4} / \mathrm{K}_{2} \mathrm{Cr}_{2} \mathrm{O}_{7}$ as oxidizing agent [4-8]. It is thus worthwhile to develop new environmentally friendly routes to these industrially important compounds. Several recent studies have focused on the selective oxidation of alkylaromatics and cycloalkanes to higher-added value ketones using green oxidizing agents like hydrogen peroxide or oxygen [9-13]. Interestingly, copper is a well known element that interacts with these oxidizing species, especially in biological systems.

Copper plays fundamental roles in living systems. These are mostly in redox processes, and it can be found in the active site of various proteins and enzymes of numerous organisms, where it is coordinated to protein residues in mono-, di-, or trinuclear complexes [13]. Some examples are: copper acts as the oxygen carrier in hemocyanins [14], and as the redox center in oxidation reactions in enzymes, such as catechol oxidase [15], dopamine monoxygenase [16], methane monoxygenase [17], and tyrosinase [18].

The use of copper complexes for the oxidation of organic compounds is promising and several approaches have been developed. Antunes et al. reported the successful oxidation of benzene, toluene and cyclohexane with hydrogen peroxide catalyzed by different $\mathrm{Cu}(\mathrm{II})$ complexes [19-21]. In our earlier study, we reported the catalytic activity of 2,2'-bipyridine and 1,10-phenantroline $\mathrm{Cu}(\mathrm{II})$ complexes in tetralin oxidation [22]. The aim of the present study is to go one step beyond with the immobilization of two complexes, $\left[\mathrm{Cu}\left(2,2^{\prime}-\mathrm{bpy}\right) \mathrm{Cl}_{2}\right]$ (1) and $\left[\mathrm{Cu}(1,10\right.$-phen $\left.) \mathrm{Cl}_{2}\right]$ (2), on polyoxometalates (POM). These heteropolycompounds are large polyanions that can be used to immobilize organic parts or organometallic complexes. However, a change in the redox properties of the grafted metal cations due to modifications in their electron transfer properties can be observed. Since these complexes are good homogeneous oxidation catalysts, we have looked at their heterogenization and hence possible recycling. The catalytic reactions were carried out using hydrogen peroxide as oxidant in an acetonitrile/water solvent at room temperature.

\section{Experimental}

\subsection{Synthesis of the $\left[\mathrm{Cu}\left(2,2^{\prime}-\mathrm{bpy}\right) \mathrm{Cl}_{2}\right]$ and $\left[\mathrm{Cu}(1,10-\right.$ phen $\left.) \mathrm{Cl}_{2}\right]$ complexes}


The detailed preparation procedure for these complexes, based on original procedures described by Meyer [23], has been reported in our earlier study [22]. The synthesis of $[\mathrm{Cu}(\mathrm{L})] \mathrm{Cl}_{2}$ was carried out by the addition of one equivalent of the 2,2'-bipyridyl ligand or 1,10-phenantroline ligand in $50 \mathrm{ml}$ of ethanol to 1 equivalent of $\mathrm{CuCl}_{2} \cdot 2 \mathrm{H}_{2} \mathrm{O}$ in $15 \mathrm{ml}$ of ethanol. The mixture was then stirred for $10 \mathrm{~min}$ at room temperature, and it formed a precipitate after a few minutes. Finally, the solvent was evaporated slowly at room temperature, and the complex was collected.

The two complexes were characterized by Fourier transform infrared (FT-IR) and elemental analysis. The results were as follows.

[Cu(2,2'-bpy) $\left.\mathrm{Cl}_{2}\right]$ (1). Light blue solid. IR ( $\mathrm{KBr}$ disc, $\mathrm{cm}^{-1}$ ): 3068, 3053, 3037, 1602, 1551, 1497, 1473, 1446, 777. Elemental analysis calculated for $\mathrm{C}_{10} \mathrm{H}_{8} \mathrm{~N}_{2} \mathrm{Cl}_{2} \mathrm{Cu}$ (\%): C, 41.27; H, 2.75; N, 9.63. Found (\%): C, 41.10; H, 2.59; N, 9.52 .

[Cu(1,10-phen) $\left.\mathrm{Cl}_{2}\right]$ (2). Light green solid. IR (KBr disc, $\mathrm{cm}^{-1}$ ): 3080, 3058, 3012, 1607, 1586, 1516, 1495, 1423, 722. Elemental analysis calculated for $\mathrm{C}_{12} \mathrm{H}_{8} \mathrm{~N}_{2} \mathrm{Cl}_{2} \mathrm{Cu}$ (\%): C, 45.78; H, 2.54; N, 8.9. Found (\%): C, 45.59; H, 2.53; N, 8.78 .

\subsection{Synthesis of $\mathrm{Cu}(\mathrm{II})$ complexes-POM organic-inorganic hybrids}

Four different hybrid materials were prepared to evaluate the influence of the ligand, number of $\mathrm{Cu}^{2+}$ cations, and immobilization methodology on oxidative properties. The Cu-complex (0.25 mmol), either (1) or (2), was dissolved in distilled water $(30 \mathrm{ml})$. 12-Tungstophosphoric acid (0.25 mmol, $\mathrm{H}_{3} \mathrm{PW}_{12} \mathrm{O}_{40}$ ) was then added. After vigorous stirring for $30 \mathrm{~min}$, the $\mathrm{pH}$ was measured $(\mathrm{pH}=3)$. The reaction mixture was transferred into a sealed Teflon reactor and heated to $160{ }^{\circ} \mathrm{C}$ under autogeneous pressure. After $65 \mathrm{~h}$ of heating, the reactor was cooled down to room temperature and the mixture was filtered and washed with distilled water (10 ml). Finally, the hybrid Cu(bpy)POM or Cu(phen)POM was collected as a colored solid, which was blue (bipyridine ligand) or green (phenantroline ligand). The synthesis yields were $42 \%$ and $33 \%$ for the immobilization of (1) and (2), respectively. These materials will be considered in the following sections as standards.

The same procedure was performed starting from 2 equivalents of (1) per equivalent of POM to carry out the grafting of complex (1) on the POM support. The following $\left[\mathrm{Cu}\left(2,2\right.\right.$ '-bpy) $\mathrm{Cl}_{2}\left[\mathrm{HPW}_{12} \mathrm{O}_{40}\right]$ complex (named as $[\mathrm{Cu}(\mathrm{bpy})]_{2} \mathrm{POM}$ ) was formed with $69 \%$ yield.

Another complex, [Cu(2,2'-bpy)Cl] $\left[\mathrm{H}_{2} \mathrm{PW}_{12} \mathrm{O}_{40}\right]$, was directly prepared by the condensation of elementary blocks by the use of hydrothermal conditions. $\mathrm{Na}_{2} \mathrm{WO}_{4}(1.058 \mathrm{~g}, 3.2$ mmol) and $\mathrm{Cu}\left(2,2^{\prime}-\mathrm{bpy}\right) \mathrm{Cl}_{2}$ (72.2 $\mathrm{mg}, 0.25 \mathrm{mmol}$ ) were dissolved in distilled water (30 ml). After stirring, a $50 \mathrm{wt} \%$ aqueous solution of $\mathrm{H}_{3} \mathrm{PO}_{4}$ was added dropwise to adjust the $\mathrm{pH}$ to 3 . The mixture was transferred into a sealed Teflon reactor and heated to $160{ }^{\circ} \mathrm{C}$. After $136 \mathrm{~h}$ of heating, the reactor was cooled down to room temperature and the solution was filtered and washed with water $(10 \mathrm{ml})$. This complex named as $\mathrm{Cu}(\mathrm{bpy}) \mathrm{POM} \mathrm{BB}$ (BB: for building blocks) was obtained in $35 \%$ yield.

\subsection{Characterization}

FT-IR spectra were recorded on a Nicolet Spectrometer 760 (CsI pellets). Elemental analyses were obtained using a Perkin-Elmer $2400 \mathrm{CHN}$ and a microbalance Perkin-Elmer AD-4 Autobalance. X-ray diffraction (XRD) patterns were acquired on a D8 Advance Bruker AXS powder diffractometer using monochromatized $\mathrm{Cu}-K_{\alpha}$ radiation in the range of $2 \theta$ from $5^{\circ}$ to $50^{\circ}$. Scanning electron microscopy (SEM) was carried out on a JEOL FEG 6700F microscope used at 9 $\mathrm{kV}$ accelerating voltage. Energy-dispersive X-ray (EDX) spectra were acquired to determine the composition of the material. The EDX spectra were acquired using $20 \mathrm{kV}$ primary electron energy. Quantification was done using the standard-less ZAF correction method with the Genesis software for EDX.

\subsection{Catalytic activity evaluation}

The different hybrid copper complexes were tested for liquid phase tetralin oxidation at room temperature. All solvents and reagents were purchased from Aldrich or Merck. The reactions were performed in a $20 \mathrm{ml}$ round-bottomed flask with vigorous stirring. This was sealed with a silicone septum in a nitrogen atmosphere. The reactions used acetonitrile as solvent, $\mathrm{H}_{2} \mathrm{O}_{2}$ as oxidant, and the $\mathrm{Cu}(\mathrm{II})$ hybrid complexes as catalysts. Immobilized $\mathrm{Cu}$ complexes on POM (0.014 mmol), tetralin (4.4 mmol), and hydrogen peroxide (131 mol) were dissolved in acetonitrile (13 ml). The copper catalyst was therefore used with a $0.3 \mathrm{~mol} \%$ loading (or $0.6 \mathrm{~mol} \%$ for the two equivalents catalyst). The reaction mixture was stirred at room temperature for up to $6 \mathrm{~d}$. The reactions were followed by a gas chromatograph (HP 5890 Series II) equipped with a DB-1 capillary column (length 30 $\mathrm{m}$, internal diameter $0.53 \mathrm{~mm}$ ). The retention times used to characterize most of the reactions products were first calibrated with standards. Relative yields were obtained by calibration with taking into account the response factors of the substrate (tetralin) and major products (1-tetralone, 2-tetralone). The turnover number (TON) used to evaluate the catalyst performance was defined as the number of substrate molecules converted per molecule of catalyst. 


\section{Results and discussion}

\subsection{Hybrid complex characterization}

Figure 1 presents the XRD patterns of the different $\left[\mathrm{Cu}(2,2\right.$ '-bpy $\left.) \mathrm{Cl}_{2}\right]$ POMs. It is noteworthy that different preparation methods for the inorganic-organic hybrid gave reflections at around $2 \theta=9^{\circ}$. This was evidence of the preservation of the Keggin structure [24]. The XRD pattern of the $\left[\mathrm{Cu}\left(1,10\right.\right.$-phen) $\left.\mathrm{Cl}_{2}\right]-\mathrm{POM}$ homolog also showed the same result (Fig. 2).

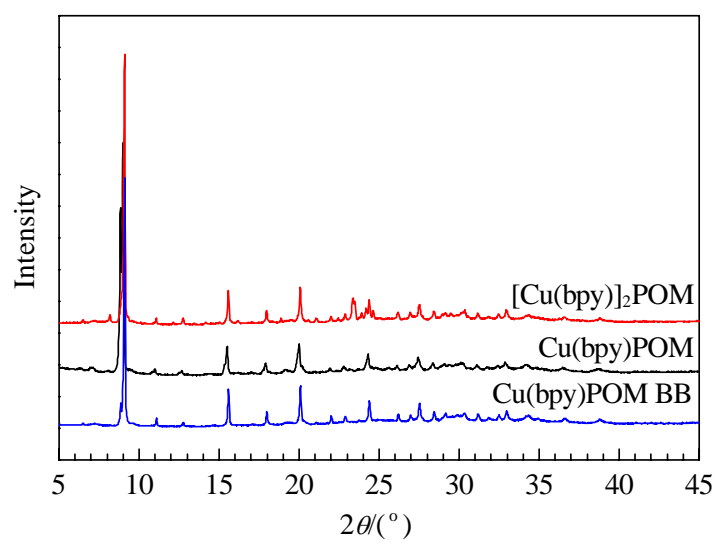

Fig. 1. XRD patterns of the different $\left[\mathrm{Cu}\left(2,2^{\prime}-\mathrm{bpy}\right) \mathrm{Cl}_{2}\right]$ grafted onto POM hybrid materials.

Since the Keggin structure was maintained after the grafting of the complexes, the immobilization strategy was successful. The microstructures of the different hybrid materials, together with elemental EDX analysis, were observed by SEM. Figure 3 shows the SEM micrographs of the three $\left[\mathrm{Cu}\left(2,2^{\prime}-\right.\right.$-bpy $\left.) \mathrm{Cl}_{2}\right]$ complexes immobilized on $\mathrm{H}_{3} \mathrm{PW}_{12} \mathrm{O}_{40}$ polyoxometalate. A dodecahedral shape was observed for the $[\mathrm{Cu}(2,2$ '-bpy $) \mathrm{Cl}]\left[\mathrm{H}_{2} \mathrm{PW}_{12} \mathrm{O}_{40}\right]$ hybrid crystals. These were between $1-3 \mu \mathrm{m}$ in size (Fig. 3(a)).

The same morphology was probably emerging for the $\left[\mathrm{Cu}(2,2\right.$ '-bpy) $\mathrm{Cl}]\left[\mathrm{H}_{2} \mathrm{PW}_{12} \mathrm{O}_{40}\right]$ hybrid obtained in situ by using elementary building blocks to assemble a Keggin-like POM (Fig. 3(b)). However, the shape remained less defined for these crystals. Surprisingly, using two equivalents of

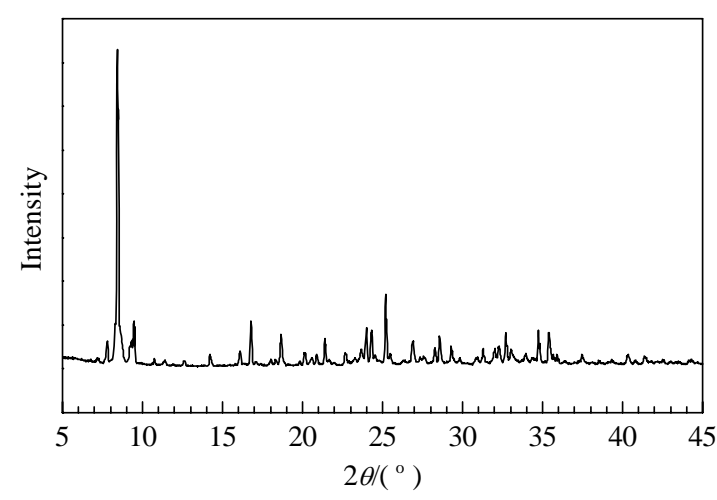

Fig. 2. XRD pattern of the $\mathrm{Cu}($ phen)POM hybrid material.

starting organometallic complex gave the growth of the cubic crystals for the $[\mathrm{Cu}(2,2 \text { '-bpy }) \mathrm{Cl}]_{2}\left[\mathrm{HPW}_{12} \mathrm{O}_{40}\right]$ hybrid material. These were also between $1-4 \mu \mathrm{m}$ in size (Fig. 3(c)). The EDX analysis (performed in the SEM chamber) confirmed the stoichiometries of the first two $\left[\mathrm{Cu}\left(2,2\right.\right.$ '-bpy)Cl] $\left[\mathrm{H}_{2} \mathrm{PW}_{12} \mathrm{O}_{40}\right]$ complexes, which was $1 \mathrm{Cu}$ atom per $12 \mathrm{~W}$ atoms. Likewise, the latter $\left[\mathrm{Cu}(2,2\right.$ '-bpy $) \mathrm{Cl}_{2}\left[\mathrm{HPW}_{12} \mathrm{O}_{40}\right]$ material basically contained 2 $\mathrm{Cu}$ atoms per Keggin unit. The immobilization of the two starting complexes was possible by simply doubling the number of equivalents. The influences of the preparation methodology, nature of starting ligand (bipyridine versus phenantroline), and amount of complexes grafted were studied by the catalytic performance of these hybrid materials in the partial oxidation of tetralin, which has been described elsewhere [22].

\subsection{Catalyst evaluation}

The catalytic activities of the complexes were investigated with the partial oxidation of tetralin to 1-tetralone and 2-tetralone as the main evidence. This is depicted in Scheme 1. The reactions were carried out at room temperature using $\mathrm{H}_{2} \mathrm{O}_{2}$ as oxidant and acetonitrile $/ \mathrm{H}_{2} \mathrm{O}(5: 1)$ as solvent. Previous studies devoted to tetralin or benzene oxidation with peroxides have shown that the starting $\left[\mathrm{CuLCl}_{2}\right]$ complexes (L: bipyridine or phenantroline) were efficient under ho-
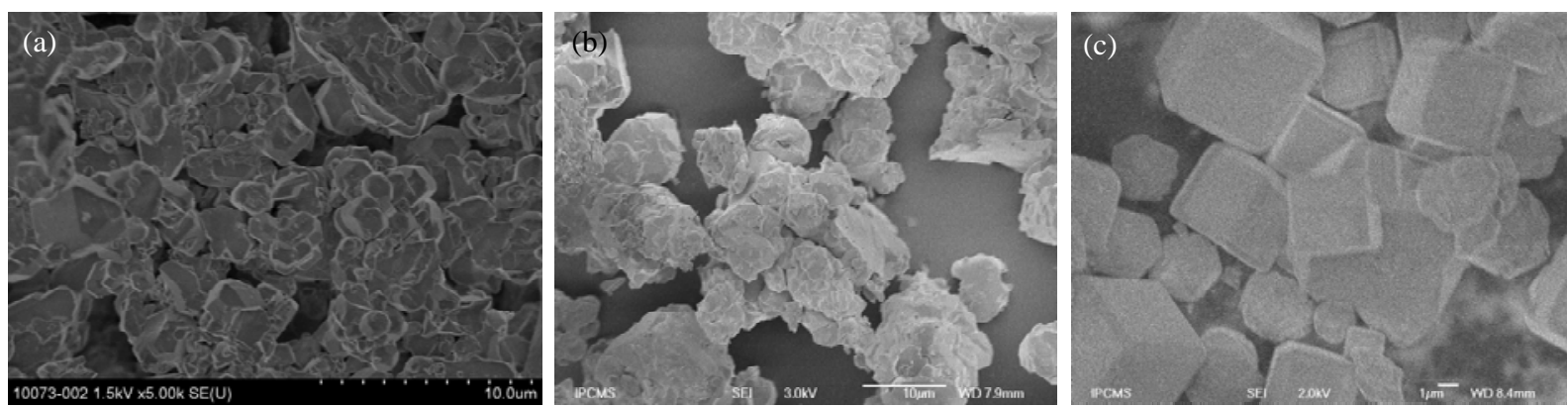

Fig. 3. SEM images of the Cu(bpy)POM (a), Cu(bpy)POM BB (b), and [Cu(bpy) $]_{2} P O M(c)$ hybrid. 


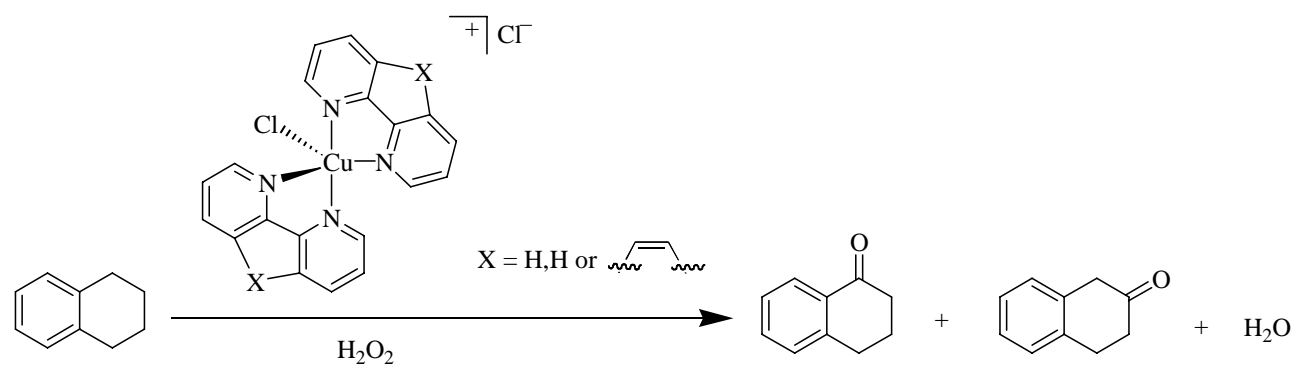

Scheme 1. Tetralin oxidation to 1-tetralone and 2-tetralone.

mogeneous conditions [19-22]. By successfully grafting the copper complexes onto a Keggin-type POM, it was possible to see the change from homogeneous to heterogeneous catalysis. This idea gives some ways to recycle the catalyst.

Figure 4 presents the tetralin conversion and tetralone selectivity of the $\mathrm{Cu}$-POM hybrid complexes. While each $\left[\mathrm{Cu}\left(2,2\right.\right.$ '-bpy)Cl] $\left[\mathrm{H}_{2} \mathrm{PW}_{12} \mathrm{O}_{40}\right]$ complex approximately yielded the same tetralin conversion (15\%), different selectivities in the two tetralin isomers were observed. $\mathrm{Cu}$ (phen)POM gave $83 \%$ selectivity, while $\mathrm{Cu}(\mathrm{bpy}) \mathrm{POM}$ and $\mathrm{Cu}$ (bpy)POM BB prepared from its elementary blocks gave lower selectivities of, respectively, 65\% and $71 \%$. These results agree with the higher selectivity achieved under homogeneous conditions with $\mathrm{CuLCl}_{2}$ complexes [22].

In contrast, an impressive $90 \%$ selectivity was observed in the oxidation over the $[\mathrm{Cu}(\mathrm{bpy})]_{2} \mathrm{POM}$ hybrid catalyst. Furthermore, it was 1-tetralone that was mainly formed (72\%). This result agreed with earlier studies that showed a different behaviour of the organic-inorganic POM hybrids of the same family [25]. Unfortunately, the catalytic activity decreased dramatically to below $10 \%$ over this highly selective catalyst. Probably, one can recover the activity of this complex using microwave heating, which was performed by Sithambaram et al. [26] for tetralin oxidation.

For comparison, the same catalytic conversions with the

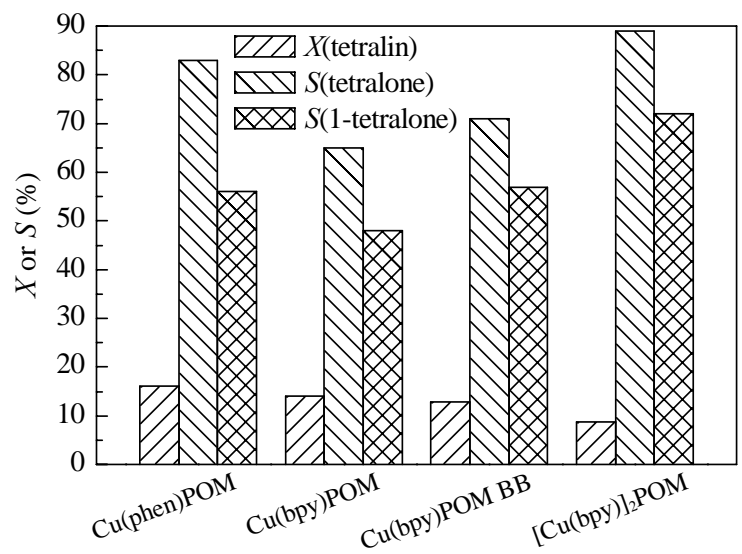

Fig. 4. Conversion of tetralin, selectivity for 1-tetralone and total ketone products (1-tetralone and 2-tetralone) obtained after $136 \mathrm{~h}$. starting $\left[\mathrm{CuLCl}_{2}\right]$ complexes were obtained under homogeneous conditions, but only after $24 \mathrm{~h}$ of reaction. In contrast, the conversions were below $2 \%$ after $24 \mathrm{~h}$ for all these hybrid $\mathrm{Cu}-\mathrm{POM}$ materials. It is therefore important to point out that the heterogenization of the $\left[\mathrm{CuLCl}_{2}\right]$ complexes onto the POM ligand led to a drastic decrease in their catalytic performances when compared to the original homogeneous complexes. This result is in agreement with that the hindered $\left[\mathrm{Cu}\left(2,2^{\prime}-\mathrm{bpy}\right)_{3} \mathrm{Cl}_{2}\right]$ complex gave only $1 \%-2 \%$ tetralin conversion after $24 \mathrm{~h}$ in a homogeneous medium. This indicated that the $\mathrm{Cu}(\mathrm{II})$ catalyst, when sterically hindered by pyridinyl and POM ligands, can hardly activate hydrogen peroxide to form copper-peroxo species. These low conversions were probably due to the filled coordination sphere of the copper center and to ligand steric hindrance, which limited access to the metal core. On the other hand, $\left[\mathrm{CuLCl}_{2}\right]$ complexes having vacant and labile positions occupied by the chloride ions were more able to perform rapid electron transfer [27].

The TON were estimated for each hybrid catalyst. A TON of 25 was achieved with the homogeneous $\left[\mathrm{CuLCl}_{2}\right]$ complex, while a TON of 9 was obtained over the hybrid materials but with the possibility to recycle these catalysts.

The possibility of catalyst recycling was evaluated by allowing the $\mathrm{Cu}$ (phen)POM catalyst to react in three consecutive runs with fresh solutions of the reactants. Unfortunately, the conversion was seriously diminished after the second run, from $16 \%$ after 136 h of reaction, down to $7 \%$. Finally, almost no catalytic activity was observed for the third catalytic run (yield in tetralone slightly above 1\%). Leaching of the active species could be responsible for this rapid decrease, especially with the use of peroxide as reported by Sheldon [28].

The mechanism of the present reaction probably includes promotion by the generation of peroxo species similar to the reaction proposed by Mimoun et al. [29] for V-peroxo complexes. Oxygen transfer from the peroxo species to the activated benzylic position of tetralin ring would occur in a bimolecular fashion. The partial oxidation would then take place by the homolytic addition of oxygen species to the substrate molecule, similar to that shown for POM catalysts 
[30].

The present results showed that the inorganic-organic hybrids here behave similarly to their homogeneous homologs. However, they gave a lower activity due to the presence of the large POM counter anion. In spite of the successful heterogenization of the $\left[\mathrm{CuLCl}_{2}\right]$ complexes via reaction with a Keggin-type POM, the catalyst could not be recycled. Nevertheless, these $\mathrm{Cu}-\mathrm{POM}$ hybrids were active at room temperature and gave excellent selectivities for 1-tetralone and 2-tetralone, especially the $[\mathrm{Cu}(\mathrm{bpy})]_{2} \mathrm{POM}$ BB hybrid catalyst.

The successful heterogenization onto POM merits further investigation [31-33]. Like enzymes, a particular ligand-metal architecture can create supramolecular interactions that can induce the formation of selective recognition sites on such hybrid materials. In contrast to steric constraints that block some reactions, these positive interactions would guide the reactants toward the active site, recognize it through specific interactions, and hence stabilize this couple in an environment for the desired chemical transformation. Targeting the same oxidation reaction, Corma and co-workers $[9,34]$ recently proposed a smart strategy to design $\mathrm{Co}$ and $\mathrm{Cu}$-containing metal organic frameworks by modifying the proportion of the two metals.

Further studies are under progress in our group to encapsulate these biomimetic $\mathrm{Cu}(\mathrm{II})$ complexes in porous silica hosts, like zeolites [35] and mesoporous silica.

\section{Acknowledgements}

The authors are grateful to Thierry Romero, Nathalie Kyritsakas-Gruber, and Suzanne Libs for their technical assistance. We would like to dedicate this contribution to Prof. O.A.C Antunes for his clever advice, friendship, and extreme kindness all the time.

\section{References}

1 Covarrubias-Zuniga A, Cantu F, Maldonado L A. J Org Chem, 2008, 63: 2918

2 Frank H G, Stadelhofer J W. Industrial Aromatic Chemistry. Berlin: Springer-Verlag, 1988

3 Mizukami F, Imamura J. US 4175 098. 1979

4 Groggins P H, Nagel R H. Ind Eng Chem, 1994, 26: 1313

5 Sanders H J, Keag H F, McCullough H S. Ind Eng Chem, 1953, 45: 2

6 Olah G A. Friedel-Crafts and Related Reactions. New York: Wiley-Interscience, 1963

7 Culius C F, Ladbury J W. J Chem Soc, 1955: 2850

8 Clark J H, Kybett A P, London P, Macquarrie D J, Martin K. J Chem Soc, Chem Commun, 1989: 1355

9 Llabrés i Xamena F X, Casanova O, Galiasso Tailleur R,
Garcia H, Corma A. J Catal, 2008, 255: 220

10 Dohi T, Takenaga N, Goto A, Fujioka H, Kita Y. J Org Chem, 2008, 73: 7365

11 Monteiro B, Gago S, Balula S S, Valente A A, Goncalves I S, Pillinger M. J Mol Catal A, 2009, 312: 23

12 Sheldon R A, Wallau M, Arends I W C E, Schuchardt U. Acc Chem Res, 1998, 31: 485

13 Cowan J A. Inorganic Biochemistry: An Introduction. New York: VCH Publishers, 1993

14 Karlin K D, Cruse R W, Gultneh Y, Farooq A, Hayes J C, Zubieta J. J Am Chem Soc, 1987, 109: 2668

15 Solomon E I, Chen P, Metz M, Lee S-K, Palmer A E. Angew Chem, Int Ed, 2001, 40: 4570

16 Friedman S, Kaufman S. J Biol Chem, 1965, 240: 4763

17 Lipscomb J D. Ann Rev Microbiol, 1994, 48: 371

18 Matoba Y, Kumagai T, Yamamoto A, Yoshitsu H, Sugiyama M. J Biol Chem, 2006, 281: 8981

19 Esmelindro M C, Oestreicher E G, Caovilla M, Lessa J A, Fernandes C, Dariva C, Egues S M, Bortoluzzi A J, Antunes O A C. J Braz Chem Soc, 2006, 17: 1551

20 Silva A C, Fernández T L, Carvalho N M F, Herbst M H, Bordinhão J, Horn-Jr A, Wardell J L, Oestreicher E G, Antunes O A C. Appl Catal A, 2007, 317: 154

21 Detoni C, Carvalho N M F, Aranda D A G, Louis B, Antunes O A C. Appl Catal A, 2009, 365: 281

22 Louis B, Detoni C, Carvalho N M F, Duarte C D, Antunes O A C. Appl Catal A, 2009, 360: 218

23 Meyer R J. Gmelins Handbuch der Anorganische Chemie. Berlin: Springer-Verlag, 1958

24 Mothé-Esteves P, Pereira M M, Arichi J, Louis B. Cryst Growth Des, 2010, 10: 371

25 Ivanova S, Nitsch X, Romero-Sarria F, Louis B, Centeno M A, Roger AC, Odriozola JA. Stud Surf Sci Catal, 2010, 175: 601

26 Sithambaram S, Nyutu E K, Suib S L. Appl Catal A, 2008, 348: 214

27 Garland M T, Grandjean D, Spodine E, Atria A M, Manssur J. Acta Crystallogr Sect C: Cryst Struct Commun, 1988, 44: 1209

28 Sheldon R A. Top Curr Chem, 1993, 164: 21

29 Mimoun H, Saussine L, Daire E, Postel M, Fischer J, Weiss R. J Am Chem Soc, 1983, 105: 3101

30 Louis B, Viswanathan B, Yuranov I, Renken A. Indian J Chem A, 2001, 40: 837

31 Dolbecq A, Dumas E, Mayer C R, Mialane P. Chem Rev, 2010, 110: 6009

32 Xu Y, Zhang K L, Zhang Y, You X Z, Xu J Q. Chem Commun, 2000: 153

33 Han Z, Zhao Y, Peng J, Ma H, Liu Q, Wang E, Hu N, Jia H. Eur J Inorg Chem, 2005: 264

34 Corma A, Garcia H, Xamena F X L. Chem Rev, 2010, 110: 4606

35 Corrêa R J, Salomão G C, Olsen M H N, Cardozo Filho L, Drago V, Fernandes C, Antunes O A C. Appl Catal A, 2008, 336: 35 